\title{
An Improved SWAT for Predicting Manganese Pollution Load at the Soil-Water Interface in a Manganese Mine Area
}

\author{
Yao Zhang ${ }^{1,2}$, Bozhi Ren ${ }^{1,2 *}$, Andrew S Hursthouse ${ }^{1,3}$, \\ Renjian Deng ${ }^{1,2}$, Baolin Hou ${ }^{1,2}$ \\ ${ }^{1}$ Hunan Provincial Key Laboratory of Shale Gas Resource Exploitation, Xiangtan, China \\ ${ }^{2}$ School of Civil Engineering, Hunan University of Science and Technology, Xiangtan, China \\ ${ }^{3}$ School of Science and Sport, University of the West of Scotland, Paisley, United Kingdom
}

Received: 12 August 2017

Accepted: 14 October 2017

\begin{abstract}
The prediction of heavy metal pollution load at the soil-water interface of a mining area was studied through an improved soil and water assessment tool (SWAT) model. The Red Flag Mining Area of Xiangtan Manganese Mine in Hunan Province, China, was selected as the research district. GPS, ARCGIS, RS technology, and field experiments were employed in this study. A modified one-dimensional migration model was embedded in the sediment migration source module of SWAT in order to establish an Improved SWAT model for the prediction of manganese pollution load at the soil-water interface. The key pollution areas identified by the improved model were consistent with actual mine pollution, with the Nash-Sutcliffe efficiency $E_{n s}$ and regression $R^{2}$ coefficients of 0.88 and 0.91 , respectively. The study would provide the theoretical foundation and scientific basis for management and repair at the site.
\end{abstract}

Keywords: improved SWAT model, soil-water interface flow, heavy metal manganese, pollution load

\section{Introduction}

Predicting pollution load at the soil-water interface is key to controlling runoff pollution in disturbed mining sites [1]. With the large-scale exploitation and smelting of ore, the solid resource and its waste (ore, waste ore, tailing sand, waste residue, etc.) result in the formation of heavy metal pollution flow in the soil-water interface under the effect of rainfall runoff [2-4]. In the long term, it could cause an increasingly prominent problem of heavy metal complex pollution in the manganese mine and the surrounding area [5]. This is particularly true for

*e-mail: renbz2016@163.com mining sites in the Hunan region of China, where largescale exploitation of metal manganese has generated large areas of degraded land.

The soil and water assessment tool (SWAT) model developed by the U.S. Department of Agriculture in 1994 is a continuous distributed watershed environment model based on GIS software [6-7]. It has been widely applied to evaluate agricultural non-point source pollution [8-9]. The SWAT model includes two main parts: land surface process and water surface/confluence process. The former considers 8 modules of hydrology, meteorology, silt, soil temperature, crop growth, nutrient, pesticide, and agricultural management for system contribution; the later completes hydrological circulation and material migration of the basin through 
2 modules of the river runoff calculation and the reservoir water balance and calculation [10-12]. SWAT has been widely applied in terms of hydrological analysis and simulation of non-point source pollution [13]. SWAT has been widely applied in the measurement of nutrients [14], pesticides [15], sediment [16-17], management [18-9], and total maximum daily loads (TMDL) water quality analysis [20] to study the formation and migration of basin non-point source pollution. However, there is less application of heavy metal pollution load in metal mine rainfall runoff. [21]. For this study we used GPS, ARCGIS, and RS technology plus field experiments. A modified onedimensional migration model was embedded in the sediment migration source module of SWAT to establish an improved SWAT model for predicting manganese pollution load at the soil-water interface.

\section{Data and Methods}

\section{Overview of the Research Area}

The study mine is in Xiangtan in central Hunan. The topography is varied with undulating hill and mountain locations, the majority lying between 100 and $800 \mathrm{~m}$ above sea level. Climate type is a subtropical monsoon climate, with the average maximum temperature of $17.4^{\circ} \mathrm{C}$. Rainfall is abundant, while the distribution of the four seasons is uneven, and annual rainfall is 1,200-1,500 mm, between 60 and $80 \%$ falling between April and October. The study area (Fig. 1), Red Flag Xiangtan Manganese Mine, covers an area of $2.6 \mathrm{~km}^{2}$ and is located in the town of Xiangtan Crane

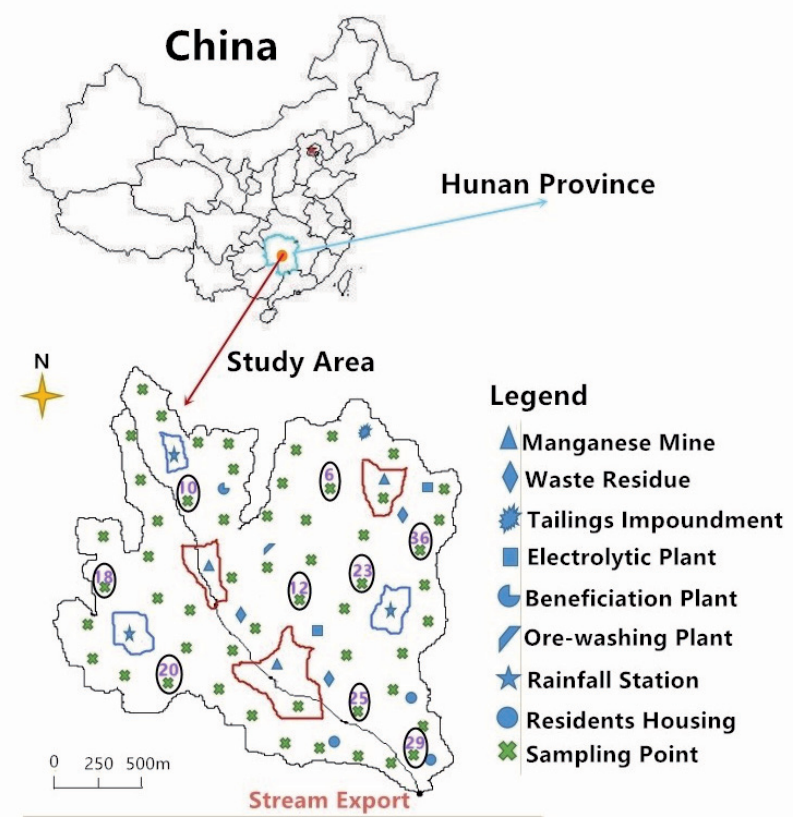

Fig. 1. Sampling point distribution and key features of the Xiangtan Manganese Mine.
Ridge $\left(112^{\circ} 21^{\prime}-112^{\circ} 75^{\prime} \mathrm{E}, 27^{\circ} 21^{\prime}-28^{\circ} 05^{\prime} \mathrm{N}\right)$ at an average altitude of $97.39 \mathrm{~m}$. A large number of ore processing activities are distributed throughout the research area, including rock crushing, electrolytic manganese recovery, washing plants, tailings dams, and other infrastructure. Three more stations were added in the study area for gaining accurate and consistent rainfall data. Based on the existing rainfall data, spatial interpolation methods were employed to predict rainfall in the sub catchment areas (Fig. 1).

\section{Sampling and Analytical Methods}

\section{Sampling and Pretreatment}

The layout of the sample collection was based on simple random points. The distribution of sampling sites was set in a way of spatial random distribution and shown in Fig. 1. At each point, a $1.0 \mathrm{~L}$ surface water samples were collected during a period of moderate water flow and distributed across all land surface types represented in the area. Each sample was labelled with latitude and longitude coordinates from GPS. Moreover, surrounding environmental information of sampling points was recorded by taking pictures. In this study, 55 soil samples were collected, and $9(6,10,12,18,20$, $23,25,29,36)$ of them were selected as representative sampling points based on the wide variety of soil type (Fig. 1).

\section{Soil Saturation Hydraulic Conductivity}

Soil saturation hydraulic conductivity is used to calculate the flow and drainage per unit time in soil profile, associating with water, time, area, and soil saturation degree (Table 1). Soil saturation hydraulic conductivity is calculated with the following formula:

$$
K_{S}=\frac{600 \times Q_{S S}}{\pi \gamma_{b}^{2}+\frac{4 \times \gamma_{b}}{a}}
$$

...where $K_{s}$ is soil saturation conductivity $(\mathrm{mm} / \mathrm{h}), Q_{s s}$ is water flux density $\left(\mathrm{cm}^{3} / \mathrm{min}\right), \gamma_{b}$ is disc radius $(\mathrm{cm})$, and $a$ is the factor associated with soil structure and capillary suction $\left(0.2 \mathrm{~cm}^{-1}\right)$.

\section{Soil Bulk Density}

Soil bulk density is associated with soil texture, structure, organic matter content, soil compactness, and cultivation measures (Table 1). And it is obtained from the following formula:

$$
\rho_{b}=M_{S} / V_{r}
$$

...where $\rho_{b}$ is soil bulk density $\left(\mathrm{g} / \mathrm{cm}^{3}\right), M_{s}$ is the quality of soil after drying $(\mathrm{g})$ and $V_{r}$ is soil volume $\left(100 \mathrm{~cm}^{3}\right)$. 
Table 1. Saturation conductivity and soil bulk density and organic carbon content from representative sampling points.

\begin{tabular}{|c|c|c|c|c|c|}
\hline Sampling point & Soil type & $\begin{array}{l}\text { Sampling depth } \\
\quad(\mathrm{cm})\end{array}$ & $\begin{array}{l}\text { Soil saturation conductivity } \\
\qquad(\mathrm{mm} / \mathrm{h})\end{array}$ & $\begin{array}{l}\text { Soil bulk } \\
\text { density }\end{array}$ & $\begin{array}{c}\text { Organic carbon } \\
\text { content }(\%)\end{array}$ \\
\hline \multirow{2}{*}{ soil_6 } & \multirow{2}{*}{ Forest red soil } & 10 & 0.69 & \multirow{2}{*}{1.256} & 0.29 \\
\hline & & 35 & 1.58 & & 0.29 \\
\hline \multirow{2}{*}{ soil_10 } & \multirow{2}{*}{ Brown soil paddy soil } & 10 & 2.41 & \multirow{2}{*}{1.325} & 1.218 \\
\hline & & 20 & 3.12 & & 0.696 \\
\hline \multirow{2}{*}{ soil_12 } & \multirow{2}{*}{ Brown calcareous soil } & 10 & 7.85 & \multirow{2}{*}{1.452} & 0.986 \\
\hline & & 20 & 41.36 & & 0.406 \\
\hline \multirow{2}{*}{ soil_18 } & \multirow{2}{*}{ Brown soil paddy soil } & 15 & 2.65 & \multirow{2}{*}{1.215} & 1.798 \\
\hline & & 30 & 3.42 & & 0.928 \\
\hline \multirow{2}{*}{ soil_20 } & \multirow{2}{*}{ Brown calcareous soil } & 10 & 6.95 & \multirow{2}{*}{1.369} & 1.218 \\
\hline & & 20 & 32.51 & & 0.753 \\
\hline \multirow{2}{*}{ soil_23 } & \multirow{2}{*}{ Forest red soil } & 15 & 2.35 & \multirow{2}{*}{1.211} & 0.132 \\
\hline & & 35 & 12.25 & & 1.042 \\
\hline \multirow{2}{*}{ soil_25 } & \multirow{2}{*}{ Brown soil paddy soil } & 10 & 2.13 & \multirow{2}{*}{1.112} & 0.928 \\
\hline & & 20 & 3.47 & & 0.58 \\
\hline \multirow{2}{*}{ soil_29 } & \multirow{2}{*}{ Brown calcareous soil } & 20 & 21.36 & \multirow{2}{*}{1.214} & 0.986 \\
\hline & & 40 & 13.54 & & 0.406 \\
\hline \multirow{2}{*}{ soil_36 } & \multirow{2}{*}{ Forest red soil } & 30 & 4.58 & \multirow{2}{*}{1.207} & 0.29 \\
\hline & & 60 & 3.41 & & 0.174 \\
\hline
\end{tabular}

\section{Soil Organic Carbon}

Organic carbon contents of samples were determined by combustion and are shown in Table 1 .

\section{Nitrogen and Phosphorus Contents}

Through the division of the study area, 18 subbasins were obtained (detailed in section 2.4). The data collection of nitrogen and phosphorus contents from these sub-basins represents the nitrogen and phosphorus properties of the entire study area. Total nitrogen was measured using the alkaline potassium persulfate digestion UV spectrophotometric method, and total phosphorus was determined with the ammonium molybdate spectrophotometric method. In this study, the content in water was multiplied by 1.1 times as the content of the interface flow. The SWAT model was able to automatically assign values to non-measurable nitrogen (Table 2).

Table 2. Nitrogen and phosphorus contents in the soil-water boundary of the sub-basin.

\begin{tabular}{|c|c|c|c|c|c|}
\hline Sub-basin & N Content $(\mathrm{mg} / \mathrm{L})$ & P Content $(\mathrm{mg} / \mathrm{L})$ & Sub-basin & N Content $(\mathrm{mg} / \mathrm{L})$ & P Content $(\mathrm{mg} / \mathrm{L})$ \\
\hline 1 & 1.20 & 1.18 & 10 & 2.31 & 2.41 \\
\hline 2 & 1.11 & 1.25 & 11 & 1.82 & 1.12 \\
\hline 3 & 4.29 & 4.24 & 12 & 2.31 & 2.01 \\
\hline 4 & 2.69 & 2.39 & 13 & 2.46 & 5.87 \\
\hline 5 & 1.87 & 1.29 & 14 & 1.67 & 1.19 \\
\hline 6 & 1.54 & 1.51 & 16 & 1.40 & 1.41 \\
\hline 7 & 5.23 & 5.02 & 17 & 1.18 & 1.21 \\
\hline 8 & 3.64 & 3.56 & 18 & & 1.10 \\
\hline 9
\end{tabular}


Table 3. Original classification and reclassification of land use type in watershed.

\begin{tabular}{|c|c|c|}
\hline \multirow{2}{*}{$\begin{array}{c}\text { Original } \\
\text { classification }\end{array}$} & \multicolumn{2}{|c|}{ Reclassification } \\
\cline { 2 - 3 } & SWAT category option & SWAT code \\
\hline Paddy field & Agricultural Land & AGRL \\
\hline Dry farm & Agricultural Land & AGRL \\
\hline Forest land & Agricultural Land & AGRL \\
\hline Open forest land & Forest-Mixed & FRST \\
\hline Grassland coverage & Pasture & PAST \\
\hline Bare land & $\begin{array}{c}\text { Southwestern U.S. } \\
\text { (arid) }\end{array}$ & SWRN \\
\hline Waterway & Water & WATR \\
\hline Swag & Water & WATR \\
\hline
\end{tabular}

All the above parameter data were collected through ARCGIS and DBF, or grid format data were generated. Then the data were imported into the SWAT model.

\section{Research Data}

\section{Data of Land Use Type}

The non-point pollution source is mainly from agriculture, varying from fertilizers (e.g., ammonium carbide and calcium superphosphate), farming methods (e.g., ox ploughing), crop types (e.g., rice and sweet potato and cole), pesticides, and their dosages. The data of land use type are shown in Table 3.

\section{Soil Type Data}

The classification of soil types in the study zone is important in determining impact of water flow and contamination in the catchment. The type and reclassification of soil are shown in Table 4.

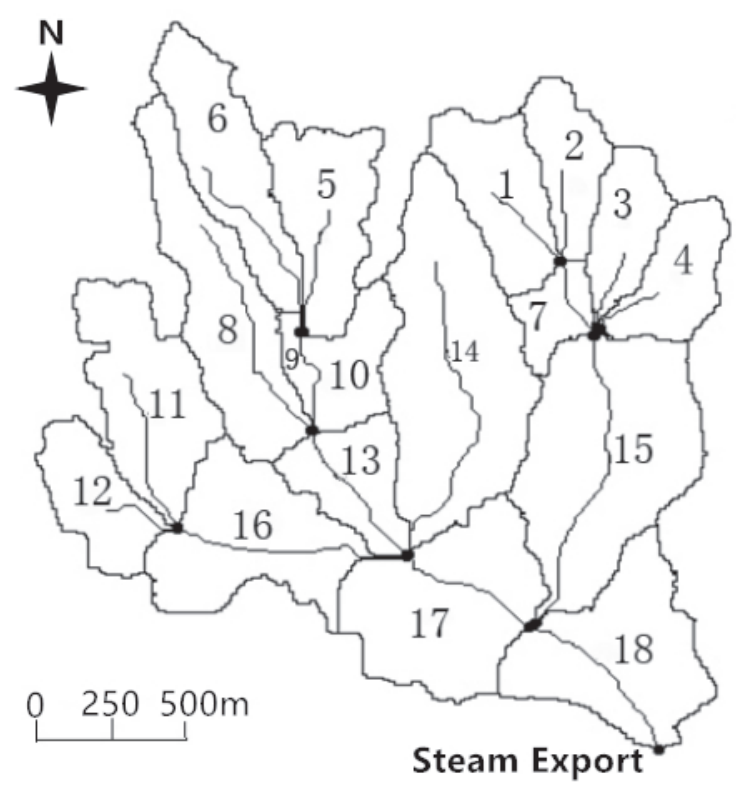

Fig. 2. Definition of sub-basins used in description of mining area.

\section{Basic Data}

In the SWAT model, input of basic data is required to be divided into spatial data and attribute data (using Alber). Spatial data: DEM reflects the elevation, slope, and gradient of the research area and is mainly used for the model's extraction of water system. A soil type distribution map reflects the spatial distribution of soil types. A land utilization type diagram reflects the status of land utilization. Attributed data: Meteorological information concludes data of 1998-2012 on rainfall, temperature, solar radiation, relative humidity, and wind speed. Hydrological information concludes initial gate size data and is used for calibration of runoff parameters. Water quality information concludes water analysis results of sampling points in the research area and is used for calibrating water quality parameters. Pollution

Table 4. Soil type classification data for representative sampling points.

\begin{tabular}{|c|c|c|c|c|}
\hline Sampling point & SWAT & Name & Soil order & Great soil group \\
\hline soil_6 & Alfisol & Brown forest soil & Brown soil & 10144 \\
\hline soil_10 & Semi-luvisols & Cinnamon soil & Calcic cinnamon soil & 11113 \\
\hline soil_12 & Pedocal & Chestnut soil & Dark chestnut soil & 12111 \\
\hline soil_18 & Primarosols & Chisley soil & Red lithosol & 15183 \\
\hline soil_20 & Primarosols & Rhogosol & Red regosol & 15193 \\
\hline soil_23 & Semi-hydromorphic soil & Mountain Meadow soil & Mountain meadow soil & 16121 \\
\hline soil_25 & Semi-hydromorphic soil & Waterlogged soil & Waterlogged soil & 16141 \\
\hline soil_29 & Lakes and reservoirs & Lakes and reservoirs & Lakes and reservoirs & 24101 \\
\hline soil_36 & Lakes and reservoirs & Lakes and reservoirs & Lakes and reservoirs & 24121 \\
\hline
\end{tabular}


source data includes discharge pollution sources of domestic, livestock breeding, aquaculture, and farmland.

\section{Definition of Sub-Basin}

According to the established database, spatial discretization in the SWAT model includes the delineation of sub-basins in the study area and the sub-division of hydrological response units (HRU). According to the locations of runoff collection points and the relationship between the each tributary, the watershed was divided into sub-basins, and then divided into several HRUs. Based on the analysis of land use and soil types, 18 sub-basins and 232 HRUs were defined (Fig. 2).

\section{Construction of Improved SWAT Model and its Operation}

\section{Improved Conversion Kinetics Model of Manganese Migration}

Manganese ion transport at the soil-water interface flow along with sediment, nitrogen, and phosphorus. Many metals transport with similar properties at the soil-water interface, which is dominated by water flow. Select the most appropriate migration model and program it in Fortran. The migration model was then embedded in the sediment migration source module of SWAT software, obtaining an improved SWAT model for predicting manganese pollution load at the soil-water interface.

Based on the comparative analysis of several important metal transfer models [22-24], the onedimensional mercury migration model of Lin was selected [25]:

$$
\frac{\partial C}{\partial t}+u \frac{\partial C}{\partial x}=\frac{1}{A} \frac{\partial}{\partial x}\left[D_{x} A \frac{\partial C}{\partial x}\right]+\frac{N}{H_{i}}
$$

The above model only considers the molecular diffusion and exchange between the heavy metal ions in a water body and river boundary, with no consideration given to the adsorption or desorption kinetics of heavy metals with the sediment. Therefore, correction factors $\delta$ and $k$ were added to the base model to accommodate the differences in sediment/water partition:

$$
\begin{gathered}
k \delta\left[\frac{\partial C^{*}}{\partial t}+u \frac{\partial C^{*}}{\partial x}\right]=\frac{1}{A} \frac{\partial}{\partial x}\left[D_{x} A \frac{\partial C^{*}}{\partial x}\right]+\frac{N}{H_{i}} \\
k=C_{s} / C_{w}
\end{gathered}
$$

...where $C$ is mercury concentration in the selected model $(\mathrm{mg} / \mathrm{L}), t$ is time (s), $D_{x}$ is longitudinal turbulent diffusion coefficient $\left(\mathrm{m}^{2} / \mathrm{s}\right), A$ is the cross-sectional area of pollution flow $\left(\mathrm{m}^{2}\right), u$ is velocity of pollution flow $(\mathrm{m} / \mathrm{s}), x$ is migration distance $(\mathrm{m}), H_{i}$ is depth of the water (m), $N$ is exchange velocity of pollutants between the bottom mud and water $(\mathrm{mg} \cdot \mathrm{m} /(\mathrm{L} \cdot \mathrm{s})), k$ is distribution coefficient, $C^{*}$ is manganese concentration to be predicted $(\mathrm{mg} / \mathrm{L}), C_{s}$ is manganese concentration on the suspended particles in the soil-water interface flow $(\mathrm{mg} / \mathrm{L}), C_{w}$ is the manganese concentration in the soil-water interface flow $(\mathrm{mg} / \mathrm{L})$, and $\delta$ is element differential correction factor.

\section{Determining $\delta$ and $k$}

It was assumed that a consistent linear empirical relationship existed between mercury and manganese migration. According to the analysis that determined concentrations in water and soil samples (data from the Environmental Protection Bureau of Xiangtan), the ratio of mercury content to manganese ranged from 0.2 to 0.8 . The improved model, by embedding Eq. (3) in the SWAT model, was run with the determined data and the data from the Environmental Protection Bureau of Xiangtan, and the Nash Sutcliffe efficiency coefficient $\left(E_{n s}\right)$ and regression coefficient $\left(R^{2}\right)$ can be calculated with the following formulas [26-27]:

$$
E_{n s}=1-\frac{\sum_{i=1}^{n}\left(Q_{i}-P_{i}\right)^{2}}{\sum_{i=1}^{n}\left(Q_{i}-\bar{Q}\right)^{2}}
$$

$$
r^{2}=\left(\frac{\sum_{i=1}^{n}\left(Q_{i}-\bar{Q}\right)\left(P_{i}-\bar{P}\right)}{\sqrt{\sum_{i=1}^{n}\left(Q_{i}-\bar{Q}\right)^{2}} \sqrt{\sum_{i=1}^{n}\left(P_{i}-\bar{P}\right)^{2}}}\right)^{2}
$$

...where $i$ is the serial number of pollutants, $N$ is total number of pollutants, $Q_{i}$ is the measured flow $\left(\mathrm{m}^{3} / \mathrm{s}\right), P_{i}$ is the analog flow $\left(\mathrm{m}^{3} / \mathrm{s}\right), \bar{Q}$ is average measured flow $\left(\mathrm{m}^{3} / \mathrm{s}\right)$, and $\bar{P}$ is average analog flow $\left(\mathrm{m}^{3} / \mathrm{s}\right)$.

When $E_{n s}$ and $R^{2}$ are closer to 1.0 , the similarity between the simulated and measured values is strong. If both values are greater than 0.85 , the degree of model fit is high and parameter adjustment is not essential. Otherwise, necessary parameters should be adjusted. The $E_{n s}$ and $R^{2}$ were both higher than 0.85 by gradually narrowing the difference and the range of $\delta$, with the final range of $[0.37734,0.37698]$. Elongation is 0.375 .

Distribution coefficient $k$ was identified with $\delta$ of 0.375 , and calculated from the experimental data of manganese mine runoff. Distribution coefficient $k$ in 18 sub-basins is shown in Table 5. 
Table 5. Distribution coefficient $k$ for Mn in each sub-basin.

\begin{tabular}{|c|c|c|c|c|c|c|c|c|c|}
\hline Sub-basin & 1 & 2 & 3 & 4 & 5 & 6 & 7 & 8 & 9 \\
\hline$k$ & 2.1 & 1.6 & 9.32 & 7.11 & 4.08 & 3.88 & 8.69 & 2.98 & 7.98 \\
\hline Sub-basin & 10 & 11 & 12 & 13 & 14 & 15 & 16 & 17 & 18 \\
\hline$k$ & 6.38 & 3.08 & 2.87 & 8.95 & 6.02 & 3.54 & 4.21 & 2.54 & 2.37 \\
\hline
\end{tabular}

\section{Operating the Improved SWAT Model}

The use of Fortran language for the integration of the manganese transformation model allows for modifying the software operation. The main steps are as follows:

1) Set the input and output parameters. The input parameters include $C$ : mercury concentration in the selected model $(\mathrm{mg} / \mathrm{L}) ; D_{r}$ : longitudinal turbulent diffusion coefficient $\left(\mathrm{m}^{2} / \mathrm{s}\right) ; A$ : the cross-sectional area of pollution flow $\left(\mathrm{m}^{2}\right)$; $u$ : velocity of pollution flow $(\mathrm{m} / \mathrm{s}) ; x$ : migration distance $(\mathrm{m}) ; H_{i}$ : water depth (m); $N$ : exchange velocity of pollutants between the bottom mud and water $(\mathrm{mg} \cdot \mathrm{m} /(\mathrm{L} \cdot \mathrm{s})) ; C_{s}$ : manganese concentration on the suspended particles in the soil-water interface flow $(\mathrm{mg} / \mathrm{L}) ; C_{w}$ : manganese concentration in the soil-water interface flow $(\mathrm{mg} / \mathrm{L}) ; C^{*}$ : manganese concentration to be predicted $(\mathrm{mg} / \mathrm{L})$.

2) Define intermediate parameter: the distribution coefficient $\mathrm{k}$ and element difference correction factor $\delta$.

3) Program subroutines and functional functions. The one-dimensional transformation model for manganese was programmed with Fortran. Then the one-dimensional model was embedded into SWAT. The results were obtained from the operation of the SWAT model, and displayed output in the final data set.

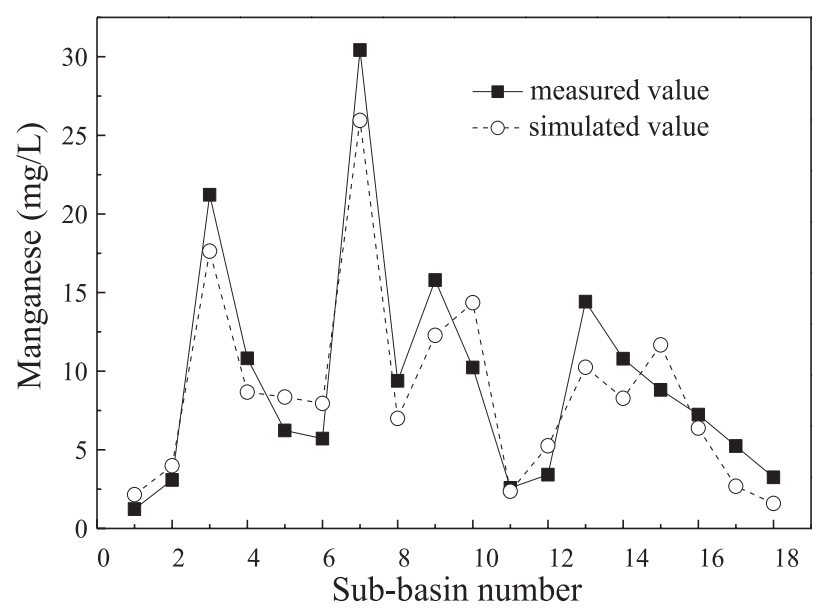

Fig. 3. Comparison between measured and simulated values of initial operation for Mn pollution load in each sub-basin in 2012.

\section{Model Validation and Results Analyses}

Initial Operational Results for Improved SWAT

Initial operation was conducted with the determination of sensitivity parameters. The actual situation has some degree of discrepancy. Therefore, it is necessary to adjust the parameters in the later stage and re-run the model. The output results of initial operation and the comparison of simulated values with measured values for the improved model are summarized in Fig. 3.

\section{Calibrating and Validating the Parameters}

The improved SWAT model has 60 parameters, and before the model was calibrated and validated, a sensitivity analysis was carried out using the LHOAT method with the advantage of previous global and local analysis tests [28-29]. Finally, 10 sensitivity parameters were selected: runoff curve number $\left(\mathrm{CN}_{2}\right)$, evaporation compensation coefficient of the soil (ESCO), available water of the soil (SOL_AWC), basis flow coefficient (ALPHA_BF), groundwater re-evaporation coefficient (GW_REVAP), surface runoff coefficient (SURLAG), linear index of the silt re-carried (SPCON), effective hydraulic conductivity of main river channel $\left(\mathrm{CH}_{-} \mathrm{K}_{2}\right)$, residual decomposition factor (RSDCO), and the power index of the silt re-carried (SPEXP). On

Table 6. Ranges and actual values of sensitivity parameters in the improved SWAT model.

\begin{tabular}{|c|c|c|}
\hline Sensitive parameters & Value range & Actual value \\
\hline $\mathrm{CN}_{2}$ & $35-98$ & 54 \\
\hline ESCO & $0.01-1$ & 0.7 \\
\hline SOL_AWC & $0.1-1$ & 0.6 \\
\hline ALPHA_BF & $0-1$ & 0.7 \\
\hline GW_REVAP & $0.02-0.2$ & 0.15 \\
\hline SURLAG & $0-10$ & 6 \\
\hline SPCON & $0.0001-0.01$ & 0.005 \\
\hline CH_K2 & $0.01-1.50$ & 1.2 \\
\hline RSDCO & $0.002-0.2$ & 0.02 \\
\hline SPEXP & $1.0-2.0$ & 1.5 \\
\hline
\end{tabular}




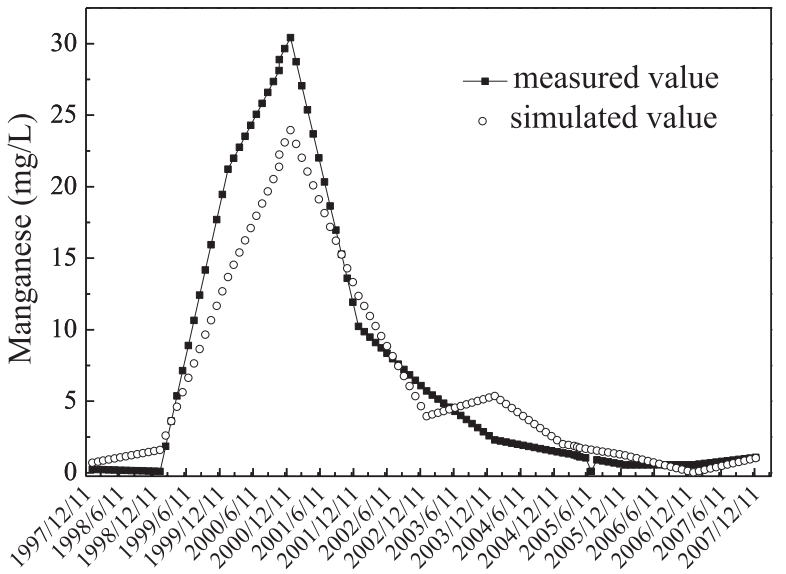

Fig. 4. Simulated and measured values of manganese pollution load from 1998 to 2007 for sub-basin 4 in the study area.

the basis of model sensitivity analysis, the SCE-UA algorithm proposed by DUAN [30-32] was applied to adjust the above sensitivity parameters and determine the numerical value of each parameter by satisfying the two-control standard for $E_{n s}$ and $R^{2}$, which are greater than 0.85 , respectively (Table 6 ).

The 1998-2002 data were used for calibration (first preliminary calibration with the annual data, then detailed calibration with the monthly data), and the 2003-2007 data were used for validation. Taking sub-basin 4 as an example, the results of the monthly calibration and validation are shown in Fig. 4.

Through the calibration of the 1998-2002 data of sub-basin $4, E_{n s}$ and $R^{2}$ were 0.85 and 0.88 , respectively. $E_{n s}$ and $R^{2}$ for the validation of the 2003-2007 data were 0.87 and 0.90 , respectively. After the calibration and validation of the above sensitivity parameters, the final results of the improved SWAT model were obtained (Fig. 5), the fitting degree of which was higher than that before calibration and validation (Fig. 3).

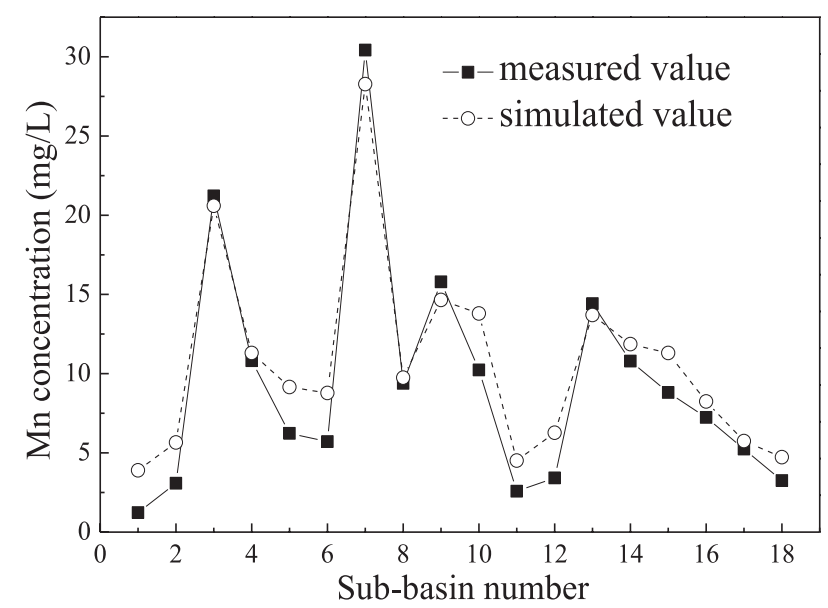

Fig. 5. Measured and simulated values after calibration and validation of manganese pollution load for each sub-basin in 2012.

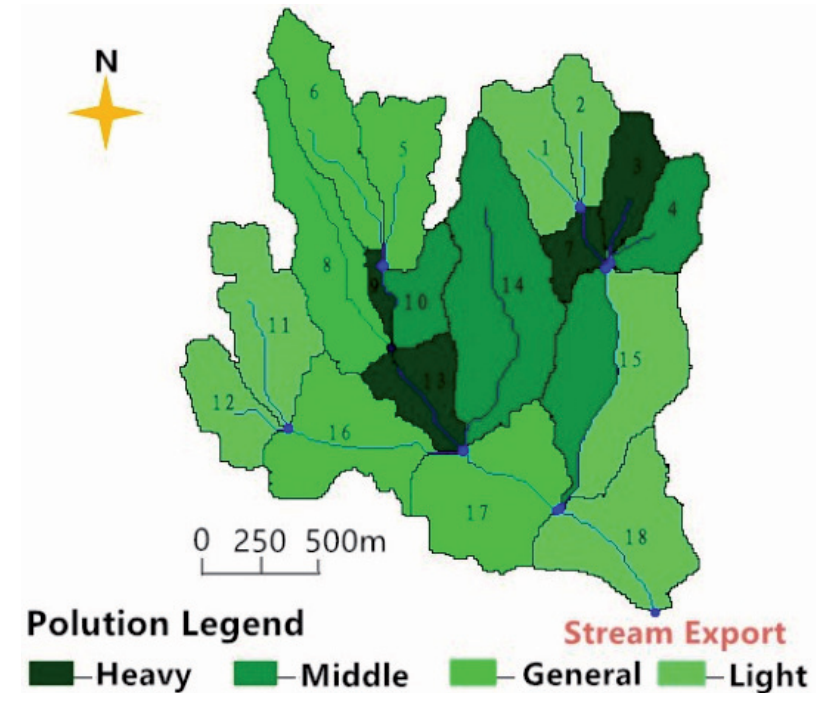

Fig. 6. Manganese pollution status in the study area.

\section{Operational Result and Analysis after Adjusting Parameters}

Based on the simulation results of the improved SWAT model, the distribution of manganese pollution load in the study area was derived using ARCGIS and RS. The pollution classification bands were defined as: less than $1.00 \mathrm{mg} / \mathrm{L}$ for light pollution, $1.00-5.00 \mathrm{mg} / \mathrm{L}$ for general pollution, $5.00-10.00 \mathrm{mg} / \mathrm{L}$ for middle pollution, and higher than $10.00 \mathrm{mg} / \mathrm{L}$ for heavy pollution. Manganese pollution of the area identified by the improved SWAT model is shown in Fig. 6.

The results showed that there was quite a good degree of fit between the actual measured manganese contents and the simulated values $\left(E_{n s}=0.88\right.$, $\left.R^{2}=0.91\right)$. It was shown that sub-basins 3 and 7 were heavy pollution areas, corresponding to the red flag mine export and tailings processing district. Sub-basins 9 and 13 were heavy pollution areas, corresponding to the major transport routes and slag district of the mine. The results were consistent with the actual pollution situation, demonstrating the high validity of the improved SWAT.

\section{Conclusions}

The 1D manganese migration and transformation kinetics model was obtained from the modification of 1D mercury migration and transformation model. The 1D migration model for manganese was embedded into the SWAT model to establish an improved SWAT model for predicting manganese pollution load in a manganese mine area in Hunan Province, China. The improved SWAT model exhibited a good fit between experimental and predicted data $\left(E_{n s}=0.88, R^{2}=0.91\right)$ for better prediction of heavy metal pollution load at the 
soil-water interface. The key pollution areas identified by the improved model were consistent with actual mine pollution. The model provides the potential possibility for application to other non-ferrous metal mine areas in China.

\section{Acknowledgements}

This work was supported by the National Natural Science Foundation of China (No. 41472328) and the Hunan Postgraduate Research Innovation Program (No. CX2016B559).

\section{References}

1. REN B., LIU B., ZHENG X., ZHOU Y. Source analysis of heavy metal in contaminated flow from soil-water interfaces in manganese ore zone. Environmental Pollution \& Control., 2014 [In Chinese].

2. COSTA G.B., SIMIONI C., RAMLOV F., MARASCHIN M., CHOW F., BOUZON Z.L., SCHMIDT É.C. Effects of manganese on the physiology and ultrastructure of Sargassum cymosum. Environ. Exp. Bot. 133, 24, 2017.

3. FADEL M., HASSANEIN N.M., ELSHAFEI M.M., MOSTAFA A.H., AHMED M.A., KHATER H.M. Biosorption of manganese from groundwater by biomass of Saccharomyces cerevisiae. HBRC Journal. 13, 106, 2017.

4. TEPANOSYAN G., MAGHAKYAN N., SAHAKYAN L., SAGHATELYAN A. Heavy metals pollution levels and children health risk assessment of Yerevan kindergartens soils. Ecotox. Environ. Safe. 142, 257, 2017.

5. SHEN Z.J., XU D.C., CHEN Y.S., ZHANG Z. Heavy metals translocation and accumulation from the rhizosphere soils to the edible parts of the medicinal plant Fengdan (Paeonia ostii) grown on a metal mining area, China. Ecotox. Environ. Safe. 143, 19, 2017.

6. SOMMERLOT A.R., WAGENA M.B., FUKA D.R., EASTON Z.M. Coupling the short-term global forecast system weather data with a variable source area hydrologic model. Environ. Modell. Softw. 86, 68, 2016.

7. SHI Y., XU G., WANG Y., ENGEL B.A., PENG H., ZHANG W., CHENG M., DAI M. Modelling hydrology and water quality processes in the Pengxi River basin of the Three Gorges Reservoir using the soil and water assessment tool. Agr. Water Manage. 182, 24, 2017.

8. GOLMOHAMMADI G., RUDRA R., DICKINSON T., GOEL P., VELIZ M. Predicting the temporal variation of flow contributing areas using SWAT. J. Hydrol. 547, 375, 2017.

9. SINNATHAMBY S., DOUGLAS-MANKIN K.R., CRAIGE C. Field-scale calibration of crop-yield parameters in the Soil and Water Assessment Tool (SWAT). Agr. Water Manage. 180, Part A, 61, 2017.

10. WOLDESENBET T.A., ELAGIB N.A., RIBBE L., HEINRICH J. Hydrological responses to land use/cover changes in the source region of the Upper Blue Nile Basin, Ethiopia. Sci. Total Environ. 575, 724, 2017.

11. EVENSON G.R., GOLDEN H.E., LANE C.R., D AMICO E. Geographically isolated wetlands and watershed hydrology: A modified model analysis. J. Hydrol. 529 (1), $240,2015$.
12. WANG R., BOWLING L.C., CHERKAUER K.A., CIBIN R., HER Y., CHAUBEY I. Biophysical and hydrological effects of future climate change including trends in $\mathrm{CO}_{2}$, in the St. Joseph River watershed, Eastern Corn Belt. Agr. Water Manage. 180 (B), 280, 2017.

13. ROMAGNOLI M., PORTAPILA M., RIGALLI A., MAYDANA G., BURGUÉS M., GARCÍA C.M. Assessment of the SWAT model to simulate a watershed with limited available data in the Pampas region, Argentina. Sci. Total Environ. 596-597, 437, 2017.

14. MOLINA-NAVARRO E., ANDERSEN H.E., NIELSEN A., THODSEN H., TROLLE D. The impact of the objective function in multi-site and multi-variable calibration of the SWAT model. Environ. Modell. Softw. 93, 255, 2017.

15. CHEN H., LUO Y., POTTER C., MORAN P.J., GRIENEISEN M.L., ZHANG M. Modeling pesticide diuron loading from the San Joaquin watershed into the Sacramento-San Joaquin Delta using SWAT. Water Res. 121, 374, 2017.

16. VIGIAK O., MALAGÓ A., BOURAOUI F.A., VANMAERCKE M., OBREJA F., POESEN J., HABERSACK H., FEHÉR J., GRO ELJ S. Modelling sediment fluxes in the Danube River Basin with SWAT. Sci. Total Environ. 599-600, 992, 2017.

17. ZHANG S., FAN W., LI Y., YI Y. The influence of changes in land use and landscape patterns on soil erosion in a watershed. Sci. Total Environ. 574, 34, 2017.

18. HUANG H., OUYANG W., WU H., LIU H., ANDREA C. Long-term diffuse phosphorus pollution dynamics under the combined influence of land use and soil property variations. Sci. Total Environ. 579, 1894, 2017.

19. SOMMERLOT A.R., WAGENA M.B., FUKA D.R., EASTON Z.M. Coupling the short-term global forecast system weather data with a variable source area hydrologic model. Environ. Modell. Softw. 86, 68, 2016.

20. ALIGHALEHBABAKHANI F., MILLER C.J., SELEGEAN J.P., BARKACH J., SADATIYAN ABKENAR S.M., DAHL T., BASKARAN M. Estimates of sediment trapping rates for two reservoirs in the Lake Erie watershed: Past and present scenarios. J. Hydrol. 544, 147, 2017.

21. KIM M., BOITHIAS L., CHO K.H., SILVERA N., THAMMAHACKSA C., LATSACHACK K., ROCHELLE-NEWALL E., SENGTAHEUANGHOUNG O., PIERRET A., PACHEPSKY Y.A., RIBOLZI O. Hydrological modeling of Fecal Indicator Bacteria in a tropical mountain catchment. Water Res. 119, 102, 2017.

22. ROSSINI E., KNAPP E. Protonation equilibria of transition metal complexes: From model systems toward the Mn-complex in photosystem II. Coordin. Chem. Rev. 345, 16, 2017.

23. VERNUCCIO S., GOY R., MEIER A., RUDOLF VON ROHR P., MEDLOCK J. Kinetics and mass transfer of the hydrogenation of 2-methyl-3-butyn-2-ol in a structured $\mathrm{Pd} / \mathrm{ZnO} / \mathrm{Al}_{2} \mathrm{O}_{3}$ reactor. Chem. Eng. J. 316, 121, 2017.

24. GUIZA S. Biosorption of heavy metal from aqueous solution using cellulosic waste orange peel. Ecol. Eng. 99, 134, 2017.

25. LIN Y. Study on the sediment transport model of mercury polluted river. Acta Scientiae Circumstantiae, 3, 276, 1985 [In Chinese].

26. AMIN M.G.M., VEITH T.L., COLLICK A.S., KARSTEN H.D., BUDA A.R. Simulating hydrological and nonpoint source pollution processes in a karst watershed: A variable source area hydrology model evaluation. Agr. Water Manage. 180 (B), 212, 2017. 
27. ZCAN Z., BA KAN O.U., DÜZGÜN H.E., KENTEL E.I., ALP E. A pollution fate and transport model application in a semi-arid region: Is some number better than no number? Sci. Total Environ. 595, 425, 2017.

28. PARK Y., CHO K.H., PARK J., CHA S.M., KIM J.H. Development of early-warning protocol for predicting chlorophyll-a concentration using machine learning models in freshwater and estuarine reservoirs, Korea. Sci. Total Environ. 502, 31, 2015.

29. YOUNGWOOK J., DONGSHIG O., MEEJEONG K., JAEWOO P. Calibration of LEACHN model using LHOAT sensitivity analysis. Nutr. Cycl. Agroecosys. 87, 261, 2010.
30. DUAN Q., SOROOSHIAN S., GUPTA V.K. Optimal use of the SCE-UA global optimization method for calibrating watershed models. J. Hydrol. 158, 265, 1994.

31. KETABCHI H., ATAIEASHTIANI B. Evolutionary algorithms for the optimal management of coastal groundwater: A comparative study toward future challenges. J. Hydrol. 520, 193, 2015.

32. GHORBANI M.A., KHATIBI R., GOEL A., FAZELIFARD M.H., AZANI A. Modeling river discharge time series using support vector machine and artificial neural networks. Environ. Earth Sci. 75, 1, 2016. 